\title{
Chinese Experience with Global 3G Standard-Setting
}

\author{
JOHN WHALLEY \\ WEIMIN ZHOU \\ XIAOPENG AN
}

CESIFO WORKING PAPER NO. 2537

CATEgORY 5: Fiscal POLICY, MACROECONOMICS AND GROWTH

FEBRUARY 2009

\footnotetext{
An electronic version of the paper may be downloaded

- from the SSRN website:

www.SSRN.com

- from the RePEc website:

- from the CESifo website:

www.RePEc.org

www.CESifo-group.org/wp
} 


\title{
Chinese Experience with Global 3G Standard-Setting
}

\begin{abstract}
China's growth strategy as set out in the $11^{\text {th }} 5$-year plan in 2005 called for upgrading of product quality, the development of an innovation society, and reduced reliance on foreign intellectual property with high license fees. Consistent with this policy, China has been involved in recent years with the development of a Chinese standard in third generation $(3 \mathrm{G})$ mobile phone technology, both in negotiating the standard and seeing it through to commercialization. This is the first case of a developing country both originating and successfully negotiating a telecommunications standard and this experience raises issues for China's future development strategy based on product and process upgrading in manufacturing. We argue that while precedent setting from an international negotiating point of view, the experience has thus far is unproven commercially. But the lessons learned will benefit future related efforts in follow-on technologies if similar Chinese efforts are made.

This paper documents Chinese standard-setting efforts from proposal submission to ITU to the current large-scale trial network deployment in China and overseas trial networks deployment. We discuss the underlying objectives for this initiative, evaluate its effectiveness, and assess its broader implications for Chinese development policy.
\end{abstract}

JEL Code: O57.

\author{
John Whalley \\ University of Western Ontario / Canada \\ jwhalley@uwo.ca
}

Weimin Zhou

University of Western Ontario

wzhou45@uwo.ca
Xiaopeng An

China Center for Information Industry

Development

\section{December 2008}

We are grateful to The Center for International Governance Innovation (CIGI) for support of this work, and to Yao Li, Xin Xian, Shunming Zhang, Yuezhou Cai, Yan Dong, and Huifang Tian for comments. The first author also acknowledges the support of the Leibnitz Foundation, Germany, under their "Reinventing Europe" programme. 


\section{Introduction}

China's growth strategy as set out in the $11^{\text {th }} 5$-year plan in 2005 called for upgrading of product quality, the development of an innovation society, and reduced reliance on foreign intellectual property with high license fees. This policy is reflected in Chinese efforts in global standard setting for the third generation $(3 \mathrm{G})$ of a wireless telecommunications standard. China successfully negotiated the adoption of its own standard (TD-SCDMA) in the International Telecommunications Union in 2000, and Chinese enterprises have been engaged in its commercial development since. Most recently, the allocation of licenses has been announced. Here we both document and evaluate this experience.

In the history of wireless technology development, only the EU, the United States, Japan and more recently South Korea have participated in standards setting activities. This is the first time that a non-OECD / developing country has participated in this firm concentrated and highly R\&D-intensive area of activity. The Chinese third generation wireless standard (3G) is named TD-SCDMA (Time Division - Synchronous Code Division Multiple Access), and since its initial submission as a response to a call for proposal by the International Telecommunications Union (ITU) in 1997 it has received substantial support from the Chinese government in both negotiation and commercialization. More recently, after eight years of development, TD-SCDMA has moved on from a concept to a fledging industry. A large-scale trial network covering 10 Chinese cities is now under way and 28 more cities are planned to be covered. In overseas markets, a trial network is in service in South Korea and a commercial network has been put into use in Italy.

China's stated motives for entering this highly firm-concentrated and R\&D intensive area 
are to reduce the high license fees to foreign IPR holders, but also to put in place the basis for future standards development. Taking a broader view, this standard setting initiative is part of a growth strategy of creating an "innovative economy" covering education, R\&D, and mega projects delineated in an important state directive The Guidelines on National Medium- and Long-term Program for Science and Technology Development 2006-2020.

For China, the main challenge posed by this standard setting experience has come in finding successful commercialization. The appropriate commercialization strategy for the government to follow is unclear from literature. The TD-SCDMA standard has yet to receive wide deployment in either domestic or overseas markets. It has also been hard to follow other countries' experience due to difference in technology capacity, market position and other factors.

Another challenge has been the emergence of an alternative system which claims to be an advance on all the current major wireless systems including TD-SCDMA - the IP-based WiMAX system which has higher data rate transmission and lower costs with wider coverage per base station. A problem, therefore, is that even if the commercialization succeeds, it may soon be overtaken by WiMAX. Critics of WiMAX argue that it is poor in mobility which is supposedly an important feature of wireless mobile system. Nevertheless, WiMAX has already been deployed by Sprint and Clearwire in the US, and SK in Korea.

Thus challenges remain for China in further commercialization and market deployment of the TD-SCDMA standard. But China's commitment to its deployment, especially in the domestic market, is unwavering. They claim that the trial TD-SCDMA network covering 10 cities is currently the largest network in the world, and with learning-by-doing the technology 
is expected to improve further and has the potential to overtake the other two standards which are currently more advanced in technological maturity. In May 2008, Chinese government carried out the restructuring of telecommunications operators ${ }^{2}$ which was widely thought to precede the final issuance of repeatedly postponed $3 \mathrm{G}$ licenses. Recently the Minister for Industry and Information Technology has announced how the third-generation (3G) mobile telecom licenses will be issued to Chinese operators at the beginning of $2009^{3}$.

In the sections that follow, we document Chinese participation both in the global $3 \mathrm{G}$ standards negotiation and the subsequent commercialization of China's homegrown standard. This is followed by a brief exploration of its future given the competitive emergence of an alternative technology WiMAX. We then evaluate the likely success of this initiative in both the short and long term, stressing the challenges in commercialization beyond the negotiation of the standard.

\section{Chinese 3G Global Standards Negotiation}

We first discuss the successful negotiation of the Chinese 3G standard in the International Telecommunications Union (ITU) in 2000, the first such standard negotiated by a developing country. The 3G negotiation was different from the standard setting experience in the first and second generations of wireless standards where nation or regional entities (i.e. the European Union) played a dominant role. The third generation was initiated and harmonized by ITU, a

\footnotetext{
2 On May 24th, 2008, the Ministry of Industry and Information Technology, the National Development and Reform Commission and the Ministry of Finance, PRC. jointly issued a statement of "Notification of Furthering Telecommunications Industry Reform" and announced a restructuring plan for the country's telecom operators. According to the restructuring plan, the existing six Chinese operators will be changed into the pattern of "3+1", with China Unicom's CDMA business incorporated into China Telecom to form a new China Telecom company, China Unicom's GSM network included into China Netcom to form a new China Unicom, China Tietong incorporated into China Mobile to form a new China Mobile company, and China Satcom remaining unchanged.

${ }^{3}$ See page 25 for details.
} 
UN agency ${ }^{4}$.

The ITU follows a voting policy on its decisions of equal weight per country (i.e. each member country has one vote). In recent decades the ITU has shifted from an emphasis on spectrum allocation to one on standards setting which is reflected in increased amounts of money spent on the ITU - over a quarter of a billion U.S. dollars in 2003-2004 (Ryan, 2005).

Ryan (2005) argues that the ITU's legal authority in the international telecommunications area has been diluted by regional and sovereign interests to the point that it plays mostly a voluntary consensus-seeking function. The ITU lacks legal structure (it does not have a permanent charter), and it is possible for it to dissolve at any point if member countries no longer perceive value in the consensus-building approach that it offers. Thus the ITU must achieve consensus in standards negotiation; its standards must be found to be useful, and, in spite of its long standing existence, it must constantly demonstrate its value to its members to survive.

The acceptance of the TD-SCDMA standard as one of the major 3G global standards by the ITU in 2000 was a great success for China. It is the only one successfully negotiated by a developing country in ITU $^{5}$.

\footnotetext{
4 As Ryan (2005) notes, the ITU was established in 1865 as an European organization from the outset. For more than fifty years, European powers controlled the ITU (originally called the International Telegraph Union), and its voting system favoured the largest European countries. After its involvement in World War II, the United States began to take a more active interest in participating in international telecommunications standardization efforts through the United Nations. However, the United States still viewed the ITU as a hindrance to the management of radio communications (through what it viewed as the ITU's imposition of state-imposed policies versus its own laissez-faire policies and ideals). The United States only appointed temporary ambassadors to attend ITU radio conferences. In the $1980 \mathrm{~s}$, however, the ITU began to loosen its policies, which had favoured PTTs and similar government organizations. Although U.S. participation in the ITU is still tentative, the level of U.S. involvement has continued to gain momentum ever since.

5 Suttmeier et al. (2006) note that "during the tenth five-year period (2001-2005), MOST (Ministry of Science and Technology) sponsored a series of "megaprojects" in conjunction with its "863" High-Technology Program. Among the megaprojects was a major initiative on standards titled "Key Technical Standards Project," which included R\&D support for WAPI, AVS, 3G telephony, optical networks, IP technologies, and other standards that have gained prominence. Reportedly, some 29 standards have resulted from this work, of which 13 have been submitted to ISO, IEC, or ITU for consideration". So far, only TD-SCDMA has been accepted by the international Standard Setting Organizations.
} 
The process leading to this outcome began in April 1997 when the ITU called for proposals for new Radio Transmission Technology (RTT) for IMT-2000 (the dubbed 3G standard) from around the world. Specifications for evaluation were also provided. This call reflected new emerging technology beyond the existing $2 \mathrm{G}$ standards adopted in wireless industry and the perceived need to codify and move forward with an agreed infrastructure standard.

At the start, China only formed an evaluation team headed by Shumin $\mathrm{Cao}^{6}$ and registered it with the ITU. But this facilitated China gaining knowledge of global standard setting mechanisms (e.g. In October, Shumin Cao attended an $\mathrm{ETSI}^{7}$ conference with other Chinese representatives, the first time that Chinese representatives attended such an event).

Later in 1998 the Ministry of Post and Telecommunications (MPT, the precursor of the now Ministry of Industry and Information Technology, MIIT) and the Ministry of Science and Technology (MOST) jointly held a conference and solicited suggestions for a Chinese 3G candidate proposal. During the conference, $\mathrm{Xu}$ Guanghan, a senior consultant of Telecom Science and Technology Research Institute, made a presentation on the SCDMA standard and put forward the framework of TD-SCDMA. Among all the proposals, TD-SCDMA was selected to be the sole proposal of Chinese candidate for IMT-2000.

Intensive work on drafting the standard followed. On 29 June 1998 - the last day set by the ITU for the submission of International Mobile Telecommunication 2000 (IMT-2000) standards - the China Academy of Telecom Technology (CATT), representing China as an

\footnotetext{
${ }^{6}$ Shumin Cao was head of the China 3G evaluation team; Chair of Working Group 5 of Task Group 8/1 of ITU; also head of the first Chinese telecommunications standardization organization - China Wireless Telecommunication Standard (CWTS) which was established in April, 1999 and joined 3GPP in 1999.

${ }^{7}$ ETSI stands for The European Telecommunications Standards Institute, a standard setting organization of EU.
} 
ITU member, submitted the proposal to Geneva which was signed by the Minister and two Vice-Ministers of the Ministry of Information Industry (MII). At the deadline for proposal submissions, the ITU had received 16 proposals from North America, Europe, Japan and China. Except for the TD-SCDMA proposal, all of the other proposals were from developed countries - the United States, European Union, Japan and South Korea.

During the period of proposal evaluation that followed, a Chinese evaluation team played an active role in promoting TD-SCDMA. Suttmeier et al (2006) cite an unpublished Chinese standard strategy paper in 2004 which argued that the Chinese government recognized that special measures were necessary to enhance China's effective participation in international standard-setting bodies. These included the development of expert teams who had the language ability, better knowledge of how international standardization bodies operate, and technical expertise to effectively represent China in these forums.

The IMT-2000 conference initially had the objective of consolidating all the submitted CDMA-based proposals into a single standard, and the submitted TDD proposals into another standard. This objective changed, however, as work progressed. Its final recommendation (ITU 2000a) was for five different radio interfaces to be adopted for terrestrial IMT-2000 services: The first was equivalent to the Euro-Japanese Wideband CDMA solution, the second was the U.S. CDMA2000 solution, the third was the Euro-China TDMA/CDMA hybrid (TD-SCDMA), the fourth was the evolution of D-AMPS and GSM to $\mathrm{EDGE}^{8}$, and the fifth was ETSI's DECT ${ }^{9}$.

\footnotetext{
${ }^{8}$ EDGE (Enhanced Data rates for GSM Evolution) is an extension on top of 2G standards - GSM and D-AMPS. Though recognized part of ITU's $3 \mathrm{G}$ definition, EDGE is most frequently referred to as $2.75 \mathrm{G}$. Its potential for further upgrading is limited compared to the first three.

9 DECT or Digital Enhanced Cordless Telecommunications (formerly Digital European Cordless Telephone) is an ETSI standard for digital portable phones (cordless home telephones), commonly used for domestic or corporate purposes. DECT can also be used for wireless broadband data transfers. DECT is recognized by the ITU as fulfilling the IMT-2000 requirements and thus qualifies as a $3 \mathrm{G}$ system.
} 
The first three of these were effectively $3 \mathrm{G}$ standards.

China had pursued other similar special measures in other standard setting efforts such as WAPI, but had not succeeded in gaining acceptance of their standards by international Standard-Setting Organizations (SSOs). One of the elements explaining TD-SCDMA's success was Siemens' support for TD-SCDMA as a joint partner of this technology ${ }^{10}$ and China's maneuvering in the negotiation as a third standard to be adopted alongside the EU-backed and USA-backed standards. However, whether the TD-SCDMA negotiation success represents an isolated event or whether it reflects a negotiating strategy that can also be used in the future is still unclear.

After a 3rd Generation Partnership Project (3GPP) standardization body was established in 1998, 3GPP took on the task of detailed drafting of standards ${ }^{11}$, ITU shifted towards setting global frameworks for requirements, spectrum allocations, interworking, and other matters. On 16 March 2001 at the $11^{\text {th }}$ plenary session of the 3GPP, all technical specifications of the TD-SCDMA standard were accepted by 3 GPP and were included in 3 GPP's Release $4^{12}$. Though it was claimed by Chinese press to be a breakthrough indicating that TD-SCDMA had been accepted not only by the ITU but also by an industry alliance of operators and vendors, its concrete impact awaited its commercialization.

\footnotetext{
${ }^{10}$ In order to promote a uniform standard WCDMA in Europe, the Siemens proposed TD-CDMA was abandoned, which led Siemens to switch their support to the Chinese TD-SCDMA.

$113 \mathrm{GPP}$ is dominated by ETSI - an EU standards setting organization - and only develops the 3G standards that are based on the UTRA related proposals. Therefore a sister project named Third Generation Partnership Project 2 (3GPP2) was established in January 1999 to facilitate the development of $3 \mathrm{G}$ standards for the cdma2000 related proposals.

123 GPP standards are structured as Releases, discussion of 3GPP thus frequently refers to the functionality in one release or another. Release 4 originally called the Release 2000 which added features including an all-IP Core Network.
} 


\section{TD-SCDMA Commercialization}

The commercialization of the Chinese $3 \mathrm{G}$ standard has proved to be challenging. The issues with commercializing the Chinese TD-SCDMA standard have been competition from parallel standards and new emerging technologies such as WCDMA, CDMA2000 and WiMAX financing, technology development, and finding qualified labor. These all which go beyond the process involved in the initial international standard negotiation. But these issues were already becoming evident at the time negotiation was completed. At the time CATT (China Academy of Telecom Technology) submitted the Chinese proposal to ITU, China's leading telecommunications equipment manufacturers such as Huawei and ZTE were only producing SPC exchanges, and had little experience in producing other wireless telecommunications equipment. By comparison, the other two IMT-2000 standards adopted had already been worked on for over ten years and equipment was available ${ }^{13}$.

\section{$\underline{\text { Technology Leading to TD-SCDMA }}$}

TD-SCDMA derives from SCDMA, an indigenous wireless access technology, developed by Beijing Xinwei Telecom Technology Inc, a joint venture of CATT (China Academy of Telecom Technology) and Cwill (standing for Chinese Wireless Local loop, founded by two Chinese working in the United States) founded in 1995. As a government agency, CATT has received RMB 15 million from the National Key Technologies R\&D Program under the Ministry of Science and Technology (MOST) and RMB 10 million from the State Planning Committee (precedent of National Development and Reform Commission) for SCDMA

\footnotetext{
13 The ITU had been developing IMT-2000 since 1985,, previously termed Future Public Land Mobile Telephone System (FPLMTS). In ETSI, the European standardization body, UMTS standardization started in 1990 when a sub technical committee SMG5 was established.
} 
development ${ }^{14}$. Cwill mainly provided technology. In 1998, SCDMA successfully passed a state-level pilot network test, which not only helped its subsequent deployment ${ }^{15}$ but also won support from Chinese government for the technology embedded in the new standardTD-SCDMA.

\section{Datang Telecom / Datang Mobile and Early Commercialization Activity}

The commercialization of the TD-SCDMA standard has centrally involved Datang Technology Co. Ltd., an enterprise associated with the Ministry of Information Industry at that time. Originally, development of the standard was taken up by Xin Wei, a joint venture of Datang Telecom Technology Co., Ltd. and Cwill. But at the end of 1999, when TD-SCDMA became a possible standard likely to be accepted by the ITU and with commercialization on the agenda, a difference of opinion occurred between Datang and Xin Wei over the likelihood of successful commercialization. Finally the decision was taken to transfer TD-SCDMA development to Datang.

Datang had another ally in commercializing TD-SCDMA - Siemens, and the proposed standard was based on a combination of technologies from Datang and Siemens. Their cooperation started in 1998 and focused on the development of TSM, an interim format bridging from the earlier 2G standard GSM to TD-SCDMA. Between 1998 and 2003, Siemens invested US\$ 70million in TD-SCDMA development ${ }^{16}$ and set up joint laboratories with Datang in Beijing, Munich, Berlin, Milan, Vienna and London. At one point, over 500 Siemens

\footnotetext{
14 See Nan Qiao, Yixuan Lu, TD-SCDMA Legend, http://www.cww.net.cn/zhuanti/td_scdma/default.html.

15 The indigenous nature of SCDMA also helped in it gaining government support. For example, in January, 2004, MII released a Notice for Trial Deployment of Telecommunication Infrastructure in Selected Suburban Areas, in which it stipulated that SCDMA be the only suggested wireless access system. http://www.mii.gov.cn/art/2005/12/29/art 992 4083 1.html

${ }^{16}$ Managing Director of Siemens' Mobile Network provided this data in a press conference, http://www.c-fol.net/news/content/12/20030901092516.htm
} 
researchers were working in China. However, in view of the rapid development of rival technologies, Datang decided to move to a new LCR (Low Chip Rate) format which is in hindsight proved to be the right decision. However, this change was resisted by Siemens and led to the breakup of their partnership in 2003. Soon afterwards, on August $29^{\text {th }}, 2003$, Siemens and Huawei announced the creation of a new joint venture between them with a joint investment of US\$ 100million focusing on TD-SCDMA development in which Siemens owned $51 \%$ of the equity.

Datang also began a restructuring during the commercialization of TD-SCDMA. In 2002, to speed up commercialization, Datang Mobile was spun off from Datang Telecom Technology Co. specifically to focus on this task. Its research team is comprised of three parts, one was its mother company in Beijing, i.e. those who had been conducting TD-SCDMA development, another one was from Shanghai which had engaged in GSM development, the other one was from Xi'an which had been involved in WCDMA development. By the first half of 2003, the whole research team comprised 130 researchers.

Since its establishment, Datang Mobile has faced the challenge of shortage of financial resources for commercial development ${ }^{17}$. According to $21^{\text {st }}$ Century Economy Report (2007), the funds required by Datang Mobile for regular operations were approximately RMB 400million (about US\$ 50million) annually. Their gap between expenditures and income was around RMB 200million (US\$ 25million) each year, and so subsidies and policy loans to Datang Moible become an important source of funding. It also noted that in 2003, Datang

\footnotetext{
17 A complex system like a wireless standard development requires substantial investment. GSM was mainly promoted by operators, and manufacturers only started to invest in the development of GSM after 10 operators promised to purchase their products. As a manufacturing company, Qualcomm gained wide support from American government, operators and cooperated with South Korea in the rollout of the first CDMA network.
} 
Mobile got over RMB 200 million (about US\$ 25 million) from MII and NDRC in form of special funds. After that, loans of RMB 200-300 million had been provided annually. Again in 2007, to facilitate equipment manufacturing, the China Development Bank provided a 15-year interest free loan of RMB 4.6 billion (about US\$ 580 million) to Datang Mobile which took the form of a TD-SCDMA Olympic and Commercialization Network Engineering Construction project $^{18}$

In addition, Datang Mobile's shareholding company - Datang Telecom Technology Co. also received financial support from various banks at later stages of TD-SCDMA commercialization. For example, in 2007, Datang Telecom Technology Co. received RMB 30billion (about US\$ 4billion) from the China Development Bank of which the interest rate involved was about two thirds of the commercial interest rate ${ }^{19}$.

\section{$\underline{\text { Spectrum Allocation }}$}

The commercialization of the TD-SCDMA standard has also been integrally involved with spectrum allocation. This has yet to be finalized as licenses are yet to be issued, but the decisions made in this area will influence the success of the commercialization.

At the beginning of TD-SCDMA commercialization, few operators or manufacturers except Datang were interested in this area. Even domestic wireless manufacturers, such as Huawei and ZET who had invested in WCDMA and CDMA2000, did not carry out any R\&D on TD-SCDMA. To improve market confidence, MII released a 3G spectrum allocation plan on October $23^{\text {rd }}, 2002,155 \mathrm{MHz}$ for TD-SCDMA (a core spectrum range of $55 \mathrm{M}$ [1880 1920M, 2010 2025M] plus an extra spectrum range of 100M [2300 2400M]), $60 \mathrm{MHz}$

18 See "4.6 Billion RMB of Interest-free Loan Finalized, Datang Mobile's Fund Demand 3 Billion RMB This Year", 21st Century Economy Report, April 26 ${ }^{\text {th }}$, 2007, website: http://tech.sina.com.cn/t/2007-04-26/09181484475.shtml.

19 The Finance and Economy Times (Cai Jing Shi Bao). See http://www.cww.net.cn/article/html/2007/6/297/66244.htm 
for WCDMA and 60MHz for CDMA2000 which are both in the core spectrum range assigned by ITU for IMT-2000.

Currently, TD-SCDMA technology only uses the core spectrum range of 55M. The extra $100 \mathrm{MHz}$ assigned is thought to be advantageous for the global deployment of TD-SCDMA because this range is not used by WCDMA and CDMA2000. This means that the TD-SCDMA standard can be a complementary extension network when operators face spectrum shortage. An outcome of the spectrum allocation favoring TD-SCDMA deployment in the future was that Siemens announced a follow-up investment of $€ 50$ million for the development of TD-SCDMA the following day of the $3 \mathrm{G}$ spectrum allocation announcement ${ }^{20}$.

Spectrum was assigned free to operators in China during the $1 \mathrm{G}$ and $2 \mathrm{G}$ deployment, but as a scarce resource, it had been allocated by auction in most of the OECD countries. In the $3 \mathrm{G}$ spectrum allocation, auction was again widely adopted in the EU, which contributed large revenue to the governments, especially in EU (see Table 13). However, in the countrieswhere the $3 \mathrm{G}$ market did not develop as quickly as in the $2 \mathrm{G}$ era, auction license fees became a financial burden for operators. Some argued that there had been extensive overbidding and miscalculation of the licenses' value. Several firms handed back their 3G licenses or postponed the setting up of their $3 \mathrm{G}$ infrastructure, completely writing off the license fee in their accounts (Gruber, 2005). In the second half of 2006, the 3G market in Europe started to grow, and whether auction prices were reasonable or not from a long-term point of view is now an open question. For now, however, in light of the European experience the Chinese government would adopt spectrum auctions in the $3 \mathrm{G}$ deployment. This will facilitate commercialization of

\footnotetext{
${ }^{20}$ Nan Qiao, Yixuan Lu,“ TD-SCDMA Legend” http://www.cww.net.cn/zhuanti/td_scdma/default.html
} 
the TD-SCDMA standard, but at a cost to the Chinese government of revenues.

Table 13 3G Mobile licensing in selected countries

\begin{tabular}{llllll}
\hline Country & $\begin{array}{l}\text { No. of } \\
\text { licenses }\end{array}$ & $\begin{array}{l}\text { Mobile } \\
\text { incumbents }\end{array}$ & Method & Date awarded & $\begin{array}{l}\text { Total } \\
\text { amount paid (US\$ million) }\end{array}$ \\
\hline Austria & 6 & 4 & Auction & November 2000 & 618 \\
Belgium & 4 & 3 & Auction & March 2001 & 421.2 \\
Denmark & 4 & 3 & Sealed bid auction & September 2001 & 472 \\
Finland & 4 & 3 & Beauty contest & March 1999 & Nominal \\
France & 4 & 3 & Beauty contest + fee & July 2001 & 553 each, plus 1\% of revenue \\
Germany & 6 & 4 & Auction & August 2000 & 46,140 \\
Greece & 3 & 3 & Hybrid & July 2001 & 414 \\
Italy & 5 & 4 & Hybrid & October 2000 & 10,180 \\
Netherlands & 5 & 5 & Auction & July 2000 & 500 \\
Norway & 4 & 2 & Beauty contest + fee & November 2000 & 88 \\
Spain & 4 & 3 & Beauty contest + fee & March 2000 & 480 \\
Sweden & 4 & 3 & Beauty contest & December 2000 & Nominal \\
Switzerland & 4 & 2 & Auction & December 2000 & 119.8 \\
UK & 5 & 4 & Auction & April 2000 & 35,400 \\
\hline Sources: Johannes Bauer and Yu-Chieh Lin $(2004)$ & &
\end{tabular}

\section{$\underline{\text { TD-SCDMA Industry Alliance }}$}

Another element in the commercialization of the TD-SCDMA standard has been the TD-SCDMA Industry Alliance. In view of the complexity and difficulties of TD-SCDMA commercialization, and also partly due to the breakdown in cooperation between Datang Mobile and Siemens, under the call of three Chinese government agencies - MII, NDRC and MOST, an industry alliance for TD-SCDMA was established in October 2002, with eight Chinese manufacturers as the initiators including the four leaders in Chinese telecommunications infrastructure equipment manufacturing industry, Datang Mobile, Huawei, ZTE and Potevio. In 2003, six more domestic companies joined. Four of them were chip developers who aimed to rapidly improve chip design and manufacturing capacity which had also been a weak link in the Chinese wireless industry chain.

The alliance also received public subsidies from the government. For example, in 2004, 
MII, NDRC and MOST jointly set up the TD-SCDMA R\&D and Industrialization Project investing RMB 768million (about US\$ 100million) to support the TD-SCDMA Industry Alliance ${ }^{21}$.

As in the case of other technologies such as WAPI (WLAN Authentication and Privacy Infrastructure), the TD-SCDMA alliance intended to gain support from foreign companies by encouraging them to partner with Chinese domestic manufacturers. This was expected to speed up the development of TD-SCDMA, and also to facilitate the acceptance of TD-SCDMA products by the world market. In turn, foreign companies were also to gain profile in the Chinese market.

In the infrastructure equipment manufacturing sector, four partnering organizations involving Chinese companies and leading foreign firms have been established. They are Datang Mobile and Alcatel (Alcatel received 3\% ownership of Datang Mobile for RMB 300million, with additional RMB 100million for R\&D in antenna development), Huawei and Siemens (they created a joint venture called TD Tech Ltd. in which Siemens has 51\% ownership), ZTE and Ericsson (they reached a strategic cooperative agreement), and Potevio and Nokia (they created a joint venture in October 2005 in which Potevio has 51\% ownership).

In the terminal sector, chip development has been a weak link for Chinese terminal manufacturing. To strengthen this link, three state enterprises - T3G, Commit and Datang were established during 2002 and 2003. T3G was established by Philips (in 2006, Philips Semiconductors was spun off from Royal Philips and became NXP), Datang Mobile and Samsung in January 2003. Motorola later joined as a new shareholder in 2005. Commit was

${ }^{21}$ See http://it.sohu.com/20070703/n250884236.shtml. 
established in 2002 by 17 leading domestic and foreign manufacturers, including Potevio, the CATT (China Academy of Telecom Technology), Texas Instruments (China), Nokia (China) Investment Co. Limited and LG Electronics, Inc. Commit later went bankrupt due to a shortage of funding in the first half of 2008 .

Another related chip development company is Spectrum Communications, established by overseas Chinese Ping Wu in Silicon Valley in April 2001. This company has grown rapidly over the past few years, and now has R\&D centers and branch offices both in the U.S. (Silicon Valley, San Diego) and in China (Shanghai, Beijing, Shenzhen). In 2003, it successfully developed the SC6600B, the world's first GSM/GPRS (2.5G) baseband chip with integrated multimedia and power management functions. A year later, it developed the SC8800A, the world's first single chip dual-mode TD-SCDMA/GSM baseband chip. After that, a series of upgraded chips were developed before February 2007. 8 versions were released, the latest one being SC8800H, a single chip solution which supports HSDPA/TD-SCDMA/GSM/GPRS/EDGE. As stated on Spreadtrum's homepage, its products support a broad range of wireless communications standards, including GSM, GPRS, EDGE, TD-SCDMA, W-CDMA, HSDPA, HSUPA, as well as future standards of wireless communication. Its financial operations have also been successful. In June 2007, it completed an initial public offering and listing on NASDAQ stock market exchange. In January 2008, it acquired US-based RFIC design company - Quorum Systems, Inc. According to a Merrill Lynch report released in October, 2006, Spreadtrum had 10\% of China GSM/GPRS market ${ }^{22}$. These developments implied both that access to the TD-SCDMA standard could grow through these chip developments and also ${ }^{22}$ The other major competitors on China market are MTK (40\%), TI (23\%), ADI (10\%), Philips (6\%), Agere (4\%), Inflieon
(3\%), in brackets are their market shares. See http://www.eefocus.com/html/06-12/120_1166415091.shtml. 
that competitive technologies were also more widely available.

Recently, China Mobile joined this alliance in July, 2008, being the first operator member of this alliance. China Mobile is the best performing telecommunications operator in China, its participation is expected to have influential impact on the TD-SCDMA commercialization.

So far, leveraging Chinese government's support, the TD-SCDMA alliance has covered the whole industry chain including operating, manufacturing (e.g., chipset, platform software, handset, antenna, infrastructure equipment and testing instruments) and sales channeling. Currently, the alliance has 58 members, providing technologies over the whole industry chain of TD-SCDMA system which includes (Appendix A shows the first 40 members as of 2006).

\section{TD-SCDMA Forum}

A further related element of the commercialization of TD-SCDMA has been the TD-SCDMA Forum. Similar to other promoting bodies of wireless systems such as GSM Association (GSMA) and CDMA Development Group (CDG) ${ }^{23}$, TD-SCDMA Forum was established to promote the technology after it was approved by ITU as one of IMT-2000 standards. These organizations include both manufacturers and operators from all over the world and aim to provide a platform for all stakeholders to communicate and coordinate. Among the co-founders of the Forum were China Mobile, China Telecom, China Unicom, Datang, Huawei, Motorola, Nortel and Siemens. The Forum was accepted by the 3GPP $\left(3^{\text {rd }}\right.$ Generation Partnership Project) as its MRP (Market Representative Partner) in 2005. The Forum also signed partnership agreements with major international telecom organizations, such as GSMA and CDG. The Forum now has over 300 members from more than 30 countries,

\footnotetext{
${ }^{23}$ GSMA was committed to promoting GSM and WCDMA which are both dominantly sponsored by EU telecommunications standard setting organization, ETSI. CDG was established to promote CDMA and the evolved 3G version, CDMA 2000.
} 
covering all sectors of the value chain, namely standardization agents, operators, vendors, content providers, financial and investment organizations and research institutions.

However, compared with the GSMA and CDG bodies, its global impact is still small. For example, the GSMA was founded in 1987 by 15 operators committed to the joint development of a cross border digital system for mobile communications. Now it is a global trade association representing more than 740 GSM mobile Operator Members across 219 countries and territories around the world. In addition, over 210 Associate Members (manufacturers and suppliers) support the Association's Initiatives as key partners (GSM Association Brochure 2008).

The CDMA Development Group (CDG), founded in December 1993, is an international consortium of companies who have joined together to speed the adoption and evolution of $3 \mathrm{G}$ CDMA wireless systems around the world. The CDG comprises of CDMA service providers and manufacturers, application developers and content providers. Currently it has 108 members, including 42 Cellular, PCS and WLL Operators Members, 14 Subscriber Unit Vendors, 5 Test Equipment Vendors, 17 Other Telecommunications Companies, 17 Network Equipment Vendors, 9 Application Developers, 3 Reciprocal Members and 1 Affiliate Member (CDMA Development Group official website).

\section{$\underline{\text { Tests and National Standard Entitlement }}$}

No other wireless standard has undergone as many tests as TD-SCDMA in its commercialization. To speed up the development and maturation of the TD-SCDMA standard, under the government support, manufacturers and operators have conducted a series of laboratory and fields tests. 
These tests have helped uncover problems with the TD-SCDMA technology. For example, China Daily reported in mid-2005 that during the terminal laboratory test period, the result of a series of tests showed that the TD-SCDMA terminal performance was not satisfactory due to poor chip function, and interoperability was also not up to expectations. After further tests, in September 2005 MII released test results for TD-SCDMA, claiming that the Project has achieved remarkable breakthroughs proving the feasibility of an independent TD-SCDMA network deployment. With the initial success of the laboratory tests, on January $20^{\text {th }} 2006$, TD-SCDMA was announced to be the national standard for China's wireless telecommunications industry. The other two standards were announced to be industry standards half a year later.

After the laboratory tests, more field tests were then carried out. In December 2005, an “Application Demo Network Experiment" was initiated aiming to test the field performance of TD-SCDMA terminals. Six Chinese operators participated in this test. In February 2006, a “TD-SCDMA Scale Network Technology Application Experiment” was initiated under the joint guidance of NDRC, MOST and MII to test the field performance of the TD-SCDMA application in the presence of large traffic load and intensive coverage. It covered Beijing, Shanghai, Qingdao, Xiamen and Baoding. China Telecom, Chine Netcom and China Mobile constructed test networks in Shanghai/Baoding, Beijing/Qingdao and Xiamen respectively. In mid-November, the tests reached a "user friendly" stage during which thousands of users were invited to test the network performance. Costs for these tests were fully covered by the Chinese government. 


\section{$\underline{\text { TD-SCDMA Large-Scale Commercialization Trial Network }}$}

A large-scale TD-SCDMA commercialization trial network deployment began with China Mobile's tender invitation in April 2007. This covered 8 cities. China Telecom and China Netcom also took their deployment to 2 other cities (see Appendix B).

China Mobile finalized its selection of infrastructure vendors for the rollout of its TD-SCDMA test network in eight cities under a tender amounting to RMB 26.7 billion. According to Ovum and Jean-Charles Doineau (2007), ZTE was to win about $45.5 \%$ of the tender. Ericsson, which is the OEM for ZTE's technology, were to be granted $1.2 \%$ of the total contract. Following ZTE, Datang was to win about $27.5 \%$ of the contract. Alcatel-Lucent, through its Alcatel Shanghai Bell subsidiary as a partner of Datang was to own a subset of this contract. Potevio was granted 2.7\%. Finally TD Tech (a joint venture between Huawei and Seimens) won about $13.8 \%$ of the contract ${ }^{24}$. In sum, the major winners were those who had invested substantially in the $R \& D$ and subsequently gained better performance in the previous TD-SCDMA network tests.

Meanwhile, China Mobile began testing more than 20 types of TD-SCDMA-compliant handsets in eight cities in China. The result of the testing helped China Mobile come to the company's procurement decisions for later terminal tender. Units being tested include those from ZTE, Samsung Electronics and LG Electronics, which passed initial tests covering core technologies. In December 2007, China Mobile announced its plan to purchase 30,000 40,000 TD-SCDMA-based 3G phones via public bidding to begin tests on the third generation network. China Mobile finally purchased 60,000 TD-SCDMA mobile phones, more than its

${ }^{24}$ See http://www.telecomasia.net/article.php?id_article $=4226$ 
original plan. The tender winners were New Postcom ${ }^{25}(21,000)$, Lenovo $(10,500)$, Hisense $(10,500)$, ZTE $(9,000)$, Samsung $(4,500)$ and LG (4,500). Spreadtrum became the chip supplier to New Postcom and Lenovo, MTK to Hisense and ZTE, T3G to Samsung. A second round of terminal tender followed right afterwards and was won by Huawei, Yulong, Huali and Panda. Spreadtrum, Datang and T3G were the main chip suppliers again.

Infrastructure network construction was largely finished by January 2008. On April $1^{\text {st }}$, 2008, China Mobile initiated commercial service based on the TD-SCDMA trial network in 8 cities. Voice traffic service charges are lower than current service and there are some subsidies to handset purchaser. Also the new feature of video phone service is added. The current trial network can accommodate 8 million customers, almost 95\% of the current GPRS customers in China, the largest $3 \mathrm{G}$ network in the world. China Mobile CEO, Wang Jianzhou, clarified that the first round investment totaled RMB 15billion (over US\$2billion). China Netcom and China Unicom had also set up a TD-SCDMA network in another two cities which was taken over by China Mobile later.

According to ChinaTechNews.com released on August 21, $2008^{26}$, the Ministry of Industry and Information Technology of China has announced its approval of China Mobile's nationwide commercial trial network based on TD-SCDMA technology. The approval notification says that network construction of TD-SCDMA should be accelerated and a specific plan should be made to ensure smooth progress of the construction. It requires China Mobile to do careful research and produce a follow-up network development plan to promote the

\footnotetext{
${ }^{25}$ New Postcom is a private telecommunications company established in 2005. Based on OEM contract, it has formed strategic partnership with Datang. In the tender of the wireless infrastructure equipment initiated by China Mobile, New Postcom won $5.61 \%$. In this terminal tender, it won about $35 \%$, as a new enterprise, this achievement is really impressive and surprising.

${ }^{26}$ http://www.chinatechnews.com/2008/08/21/7313-china-mobile-will-start-nationwide-td-scdma-commercial-trial-in-china/
} 
industrialization of TD-SCDMA. At the same time, the company should contact and communicate with the relevant equipment suppliers, terminal channel suppliers and users to jointly promote the growth of the TD-SCDMA industry chain. The approval also provides an overview of the frequency of the TD-SCDMA network, the number field and the development of terminals.

Recently, China Mobile announced that the coverage of the TD-SCDMA trial would expand by another 28 cities, totaling 38 cities which demonstrates higher data service demand in a survey conducted by China Mobile ${ }^{27}$. The second round network construction plan features the compatibility with $2 \mathrm{G}$ network (GSM) and shared core network which can be used in $2 \mathrm{G}$ (i.e., GSM), 3G (i.e., TD-SCDMA and its evolved versions such as HSDPA), and even TD-LTE (i.e. 4G version of TD-SCDMA).

Currently, the deployed network infrastructure has been upgraded to a high-speed downlink packet access (HSDPA) - an enhanced version. Datang Mobile is working toward an evolution of TD-SCDMA that will eventually incorporate LTE (Long-Term Evolution) ${ }^{28}$.

\section{Overseas Exploration}

Although the test network deployment is in China, a first overseas test network was also established in South Korea. In April 2007, a TD-SCDMA trial network costing US\$ 58million entered service in South Korea. This network was jointly constructed by Datang, ZTE (base station) and Samsung (core network). SK Telecom also announced their intention of investing equivalent to around RMB 50million in R\&D for TD-SCDMA. This initial success in overseas

\footnotetext{
${ }^{27}$ http://www.cww.net.cn/news/html/2008/8/28/2008828934332452.htm

${ }^{28} \mathrm{http}: / /$ electronics.ihs.com/news/2008/abi-tdscdma-china.htm. Also for details about evolution of TD-SCDMA, please see the section.
} 
market testing reflects previous cooperation between the two countries in telecommunication technology development. More importantly, it also implies further cooperation possibilities between the two. As South Korea is advanced in $3 \mathrm{G}$ applications, its cooperation will provide a good test environment for TD-SCDMA and subsequently the two parties can both make further $\operatorname{progress}^{29}$.

The first commercial TD-SCDMA network in Europe, an outcome of the cooperation between POTEVIO and Italian MYWAVE, was put into use on September 23, 2008 ${ }^{30}$. In previous July, POTEVIO and MYWAVE jointly announced the construction of a TD-SCDMA trial network. On July $18^{\text {th }}, 2008$, the two companies signed a cooperating agreement and the construction began on September $1^{\text {st }}, 2008$. As the first commercial TD-SCDMA network in Europe, the net had been put into use on September $12^{\text {th }}$, providing R4 and HSDPA service. According to TD-SCDMA Industry Alliance, the two companies are carrying out negotiation for the next network construction. POTEVIO said it would offer the updated products for MYWAVE and further its cooperation with other foreign carriers to ship TD-SCDMA into Europe.

\section{$\underline{\text { Licensing }}$}

Chinese 3G licensing has been postponed repeatedly due to uncertainty over the maturity of the new Chinese standard and potential industry restructuring to occur along with the licensing process. With the onset of the recent financial crisis in November 2008, the Chinese government announced an economic stimulus plan which included telecommunications investment. In this context, the Minister for Industry and Information Technology announced

\footnotetext{
29 Some reports stated that small-scale TD-SCDMA test networks have also been constructed in France and Romania.

30 TD-SCDMA Industry Alliance announced "POTEVIO Set up The First Commercial TD-SCDMA Network in Europe" $<$ http://www.tdscdma-alliance.org/english/news/list.asp?id=4440>.
} 
on December 12, 2008 that third-generation (3G) mobile telecom licenses were to be issued to Chinese operators at the beginning of 2009. China Mobile will receive a license for TD-SCDMA, China Unicom and China Telecom will receive licenses for WCDMA and CDMA2000 respectively. To avoid duplication in the infrastructure investment, the Minister emphasized the necessity of agreement between the operators on infrastructure sharing before licensing ${ }^{31}$.

\section{Evaluation of China's 3G Experience}

Evaluating the success of China's efforts at TD-SCDMA standards negotiation and subsequent commercialization and the lessons it offers for similar further efforts is difficult since at this stage commercialization remains in progress. It seems fair to say that this process has been slower than at first thought, but it is still possible that major financial rewards will result. It is too early to tell. As we mention in our introduction, China's motives for engaging in this highly firm-concentrated and R\&D intensive area are to reduce license fees paid to foreign IPR holders; to set the basis for standards development; and more broadly, to integrate the standard setting initiatives into the state strategy of creating an "innovative economy". And even if for now commercialization is largely restricted to the Chinese market the first of these objectives will likely be met.

\section{$\underline{\text { License Fee Reduction }}$}

It is still too early to assess the benefits of license fee reduction from TD-SCDMA. One can claim that even if restricted to the Chinese market, a 3G Chinese standard sharply reducing

\footnotetext{
31 See "China to Award 3G Licenses in Early 2009", China Economic Review, December 15, 2008. The move is expected to generate US\$29.1 billion in investments from the three operators. According to telecom consultancy BDA China, the operators have already budgeted for US $\$ 43.4$ billion in 3G-related capital expenditure, including projects completed this year or planned for completion over the next three years.
} 
foreign royalties will pay for itself. But Kennedy (2006) claims that Chinese government has drafted two dozen industry and national standards in information technology (including TD-SCDMA), but the gains from these to China have been small. Chinese industry has not collected significant royalties from these standards, cross licensing of standards between Chinese and foreign companies has yet to occur, foreign firms have not turned over their intellectual property as a result of these standards, and products based upon these standards have met with only limited commercial success.

Not unusual for standard setting initiatives, a well-defined licensing mechanism has not yet been established for TD-SCDMA. Some Standard-Setting Organizations (SSOs) require a member whose proprietary technology is included in the standard to license that technology to other members of the SSO either free of charge or on "fair, reasonable or non-discriminatory (FRND)" terms. But the definition of FRND is unclear. Some of the key companies involved have rejected the idea of licensing on FRND terms. For example, Qualcomm overtly only negotiates with other companies on a one-to-one basis. As an outcome of its aggressive IPR policy, Qualcomm has gained a substantial amount of revenue from licensing. Table 15 shows that Qualcomm's licensing and royalty fees account for approximately 30\% of its total revenues and about twice its $R \& D$ expenses.

Table 15 Qualcomm's Patent Revenue and Other Selected Financial Items (US\$ million)

\begin{tabular}{lllllll}
\hline & 2002 & 2003 & 2004 & 2005 & 2006 & 2007 \\
\cline { 2 - 6 } Revenues & 2920 & 3847 & 4880 & 5673 & 7526 & 8871 \\
-- Licensing and royalty fees & 835 & 985 & 1366 & 1929 & 2750 & 3106 \\
-- Equipment and Services & 2086 & 2862 & 3514 & 3744 & 4776 \\
Research and development & 440 & 523 & 720 & 1011 & 1538 \\
Net income & 360 & 827 & 1720 & 2143 & 2470 \\
\hline
\end{tabular}

Source: Qualcomm Co. annual reports. 
In the still short history of standard setting competition in the wireless telecommunications industry since $1980 \mathrm{~s}$, a series of disputes have occurred between different standard sponsors and not unusually, political power is involved in the resolution. For example, during the development of GSM standard, according to a Memorandum of Understanding (MoU) released in 1987 by a large group of European telecoms operators, GSM was to become an open, non-proprietary standard with open interface requiring IPR coordination ${ }^{32}$. But Motorola, as the owner of nearly sixty of the 130 patents involved in GSM at that time, refused to cooperate in cross-licensing. Instead it chose to engage in cross-licensing only with leading companies that also had valuable patent licenses to offer in return. EU PTTs then announced that no contract would be granted to those who refused to cooperate in cross-licensing (Gessler, 2002).

In the 1990s, a well-known example of cross-licensing is between Qualcomm and Ericsson. Nokia. Qualcomm stated it was willing to grant licenses for CDMA2000, but not for the other CDMA proposals unless some conditions were met. Ericsson stated that they were prepared to grant licenses to any standard, provided that all essential IPRs pertaining to the standards would be licensed reciprocally, i.e. no other company would refuse to license their IPR (Gessler, 2002) $)^{33}$.

32 Gessler (2002) stated that "The terms for IPR cooperation are less that clear than with wording like "low cost licensing" or "cross-licensing". But the practice in Europe at that time with state-owned national monopolies, telecoms R\&D was tied to quasi-vertical integration so that not much was patented, and patents were freely licensed among (related) suppliers and component producers."

${ }^{33}$ Gessler (2002) also noted the political and diplomatic efforts involved in the dispute. He stated that "Qualcomm communicated their position to the U.S. government, which resulted in actions from the United States such as in the TransAtlantic Business Dialogues (TABD)33. Qualcomm's contention was that the adoption of WCDMA as a global standard would create technical barriers to trade for U.S. industry, and that Ericsson's IPR claims were part of such a strategy. Their lobbying with the U.S. government resulted, among other things, in a letter from Secretary of State Madeleine Albright to the European Commission, in which U.S. demands on free and fair trade were presented. The actions from the U.S. government were in part also triggered by an early decision by the European Commission to require European countries to license IMT-2000 bands to an ETSI standard (WCDMA). This was interpreted as a violation of World Trade Organization (WTO) agreements, and interaction between the United States and Europe led to a reinterpretation of the agreements. As a result, the European Commission was careful to point out that it did not mandate the ETSI UMTS standards for all operators bidding for $3 \mathrm{G}$ licenses in Europe. Instead they left the licensing procedures up to the different member states of the EU, and 
A more recent example is between Qualcomm and Nokia. The two companies had been at odds since April 2007, when the previous licensing agreement between them expired. Nokia said it should pay a lower royalty rate than it had been because it controlled important technology with its own patents.

Settling such disputes has been very costly in terms of both money and time. In the case of Qualcomm vs. Ericsson, it took the two companies three years to settle the patent lawsuit finally. As part of the settlement, Ericsson gains access to San Diego-based Qualcomm's mobile phone technology and agrees to buy its mobile phone infrastructure division for an undisclosed amount of money ${ }^{34}$. The settlement between Qualcomm and Nokia was reached in July, 2008. Mark McKechnie, an industry analyst with American Technology Research, estimated that the settlement could mean as much as $\$ 400$ million in royalties paid to Qualcomm next year based on a calculation of 2 percent royalty fee on the 100 million phones equipped with Qualcomm technology that it seemed likely to sell though a 5 percent royalty arrangement is more typical in the industry. Meanwhile, the resolution could also save Qualcomm as much as $\$ 200$ million a year in legal bills ${ }^{35}$.

Similar licensing disputes may occur with the commercialization of Chinese TD-SCDMA. This so-called indigenous Chinese standard has a substantial portion of foreign patents ${ }^{36}$ which increase the difficulty of licensing fees negotiation given the IPR policies adopted by some incumbent companies such as Qualcomm.

recommended that no standards requirements be put on the licensees."

${ }_{34}$ See "Ericsson, Qualcomm Resolve Wireless Phone Dispute" http://findarticles.com/p/articles/mi hb5553/is /ai n22392652.

${ }^{35}$ See "Qualcomm and Nokia Settle Patent Lawsuit", http://www.iht.com/articles/2008/07/24/technology/qualcomm.php.

${ }^{36}$ It is hard to estimate the number of patents in the TD-SCDMA. It varies widely in different reports, ranging from $7 \%$ to over $50 \%$ for China share in the total patents. 
In the absence of an established licensing mechanism ${ }^{37}$, an option for Chinese manufacturers and others to cope with blocking patents (e.g., system for code division multi-access communication) is to pursue alternative technologies to replace the blocking one. Both South Korea and China are currently making efforts to develop OFDM (orthogonal frequency-division multiplexing), MIMO (multiple input and multiple output) and other technologies, hoping they can be used to avoid the blocking patent. The aim is to break Qualcomm's monopoly position in the CDMA-based standard competition era.

\section{Learning as the Basis for Future Standards Development}

The experience of developing TD-SCDMA, and its success or failure, will also help build up China's know-how in negotiation and commercialization of standardization in general, which, in turn, will benefit further standard-setting activities such as 4G. This has also been an objective of Chinese policy in this area.

It is not clear which strategy that China adopted secured the success in the negotiation in ITU. One view is that Chinese negotiators maneuvered by allying with the US and EU and leveraging its promising domestic market. This tactic might not be repeatable in the follow-on standard setting negotiations, since concrete alliances need to be established based on joint technology cooperation and common commercial interests.

Also Chinese TD-SCDMA commercialization up to now remains unproven, although clearly lessons have been learned for future commercialization. One issue is the repeatedly postponed licensing which is sometimes attributed to the less than satisfactory testing performance of TD-SCDMA trial network to allow more time for the TD-SCDMA to improve

\footnotetext{
${ }^{37}$ One of the criteria of entering TD-SCDMA Industry Alliance is the sharing of IPRs which is not accepted by the incumbent wholly-owned foreign companies.
} 
its performance. This strategy of improving the success probability of a homegrown standard by facilitating its earlier deployment in the domestic market or naming it the national standard is a common practice in almost all of the countries involved in global standards setting. According to Gessler (2002)'s detailed description of the 2G and 3G standardization process in the United States and EU, it seems that though the United States claims to apply a "hands-off" approach in standards selection, the United States may have delayed the $2 \mathrm{G}$ licensing in order to give CDMA (which is sponsored mainly by an American company - Qualcomm) some time to improve its technical performance. In the $3 \mathrm{G}$ deployment, the European Commission overtly requires European countries to license IMT-2000 bands to an ETSI standard (WCDMA). Gandal, Salant and Waverman (2003) notes that "the reason for their favoring WCDMA is possibly due to the fact that it puts them on even footing with CDMA 2G equipment suppliers and operators whereas CDMA2000 would give the latter a competitive cost and time to market advantage".

The benefits of first deployment in the market are that, the first system deployed is expected to improve faster than the followers based on learning-by-doing (Arthur, 1989; Cowan, 1991; Bassanini and Dosi, 1998). Another benefit of first-mover strategy is gaining higher penetration in market expanding and leveraging network development ${ }^{38}$ (Katz and Shapiro, 1985) especially if there is no compatibility between different standard-based networks. In the case of wireless systems competition, incompatibilities can be offset by interconnection agreements between different standard network operators (Gandal, Salant and Waverman, 2003; Laffont and Tirole, 2000), but telecommunications operators still have to

\footnotetext{
${ }^{38}$ Network effects refer to the phenomenon whereby a service/good becomes more valuable as more people use it, thereby encouraging ever-increasing numbers of adopters.
} 
agree on interconnection fees based on customer base size and network performance and can maneuver on the terms of acceptance or extension of agreements. In the case of the interconnection where network effects do not play an important role, a first mover advantage can reflect Stackelberg leader-follower competition (Stackelberg,1934).

Another element of benefit from the prospective success of TD-SCDMA is its ability to produce applications programs specific to the TD-SCDMA system. The network effect deriving from complementary products also helps tilt the market in favor of TD-SCDMA. Currently mobile TV based on a Chinese indigenous application program called CMMD is applied to TD-SCDMA standard ${ }^{39}$. If more programs specific for TD-SCDMA could be developed TD-SCDMA could have a better chance to win the market.

An important factor affecting the operators' selection of standard is its potential of continual improvement where transmission data rate is the key performance indicator. All sponsors of the three main 3G standards (WCDMA, CDMA2000 and TD-SCDMA) have devoted themselves to continual evolution following the market deployment of their respective systems. The original transmission speed specified by ITU (i.e., $144 \mathrm{kbit} / \mathrm{s}$ for vehicular high speed; $384 \mathrm{kbit} / \mathrm{s}$ for medium speed; and $2048 \mathrm{kbit} / \mathrm{s}$ for indoor) is too low to realize multi-media data service function. More recent versions of the major standards ${ }^{40}$ (including TD-SCDMA) can support up to $14 \mathrm{Mbit} / \mathrm{s}$ at which speed some multi-media application programs can be better applied.

In the longer term, all these three major $3 \mathrm{G}$ standards are moving towards LTE (stands for Long Term Evolution) version, aiming to compete against an alternative wireless system

\footnotetext{
39 Another application applied to TD-SCDMA standard is video phone.

${ }^{40}$ The evolution version of WCDMA is HSDPA, HSUPA; CDMA2000 EV-DO, CDMA2000 EV-DV for CDMA2000; China also has developed its enhanced version of TD-SCDMA - HSDPA.
} 
which is developed from IP-based technology - WiMAX ${ }^{41}$. The evolution of TD-SCDMA to LTE version is supported not only by the current TD-SCDMA Industry Alliance but also, more important, by a key state R\&D project named Future Technologies for Universal Radio Environment (FuTURE) ${ }^{42}$.

The FuTURE project was initiated in 2001. Its main objective was to develop beyond 3G/4G systems. Meanwhile, it also aims to help TD-SCDMA smoothly evolve to a fourth generation technology. Liu et al. (2006) presented an evolution map from TD-SCDMA to future terrestrial universal radio environment (FuTURE) TDD in China. They suggest the evolution will occur in four phases: low chip rate (LCR), high-speed downlink/uplink packet access (HSxPA)/TD-SCDMA EV 1x, long-term evolution (LTE) TDD, and FuTURE beyond 3G TDD. Currently HSxPA has already been commercialized and used by TD-SCDMA. The evolution to LTE version is on the way as a pilot demonstration network, which claims to meet the ITU's IMT-Advanced (i.e., dubbed 4G) specifications (i.e., $100 \mathrm{Mbit} / \mathrm{s}$ for high mobility and $1 \mathrm{Gbit} / \mathrm{s}$ for low mobility), has already been successfully launched in Shanghai's Changning District at a cost of RMB 150million (about US\$ 19.2 million) ${ }^{43}$.

Another lesson from the TD-SCDMA development is how to find partners for technology development. The breakup of cooperation between Datang Mobile and Siemens as well as the

\footnotetext{
${ }^{41}$ WiMAX has emerged as one of the leading standards designed to deliver both fixed and mobile wireless broadband, backed by a consortium led by Intel, Motorola and others. Currently, it is supported by the IEEE, the global computing body, and ITU. This system is based on TCP/IP - the technology that underpins the internet. Technically it is called IEEE 802.16 standard and designed to deliver IP data traffic at multiple megabits per second over a range of several kilometers. As its designed speed is much higher than that of the original version of the three dedicated network-based systems (i.e., WCDMA, CDMA2000 and TD-SCDMA), WiMAX sponsors claim it a 4G system. However, in order to facilitate the commercialization and earlier market deployment, it applied to ITU for a 3G standard status and gained the approval on October 19th, 2007. At present, it is already being deployed by Sprint and Clearwire in the US and SK in Korea.

${ }^{42}$ It is a National High-Tech R\&D Program labeled "863" FuTURE project. For details about China's Science and Technology system, please see Whalley and Zhou (2007).

${ }_{43}$ China claims that this pilot network is the world's first $4 \mathrm{G}$ mobile communications trial system. Before that in September 2006 Samsung Electronics claimed at the annual Samsung 4G Forum in Jeju Island that it had developed the world's first demonstration of $4 \mathrm{G}$ mobile technology whose data rates have reached $100 \mathrm{Mbps}$ on a vehicle moving at up to $60 \mathrm{kms} / \mathrm{hr}$, with cell-to-cell handover, and up to $1 \mathrm{Gbps}$ inside the exhibition area.
} 
bankruptcy of Commit demonstrate the difficulty of finding appropriate partners. Maybe a result of the difficulty in partnering with western MNCs is that during the execution of FuTURE project cooperation is more likely found to be with South Korean and Japanese companies based on their common interests in lowering licensing fees. For example, a memorandum was signed by four standard setting organizations from China, Japan and South Korea in 2002 which specifically identified $4 \mathrm{G}$ as a focus cooperation area ${ }^{44}$.

A further element of potential benefit from TD-SCDMA is its potential evolution over time as a lower cost standard, and the learning from this experience for other possible technologies. Kennedy (2006) discusses WAPI (Wired Authentication and Privacy Infrastructure) as a new national technical standards strategy that could lead to conflict with the international community over standard-setting. Other related initiatives include product tracking and remote identification (RFID), digital audio-video coding and decoding (AVS), the formats of audio-video disc players (EVD), and digital home networking and next-generation internet protocols. Standards-setting for the high-technology industry in China is clearly a complex matter. At the same time, China's standards strategy is part of the wider technology development strategy being followed.

\section{$\underline{\text { Standards as Part of the National Strategy of an "Innovative Economy" }}$}

China's activity in international standards setting has to be seen as part of China's wider development policy. This is based on ever deeper integration into the global economy, continual product quality upgrading to underpin export growth, and reduced reliance on

\footnotetext{
44 On November 7th, 2002, four standard organizations in China, Japan and Korea (namely, CCSA, ARIB, TTC and TTA) signed a MoU for mutual cooperation in the growth and development of the information and telecommunication industries of the three countries. They agreed to mutually exchange views and information on the status of the industries and to contribute to the works of standard organizations of regional and global levels through cooperation (ITU, 2003). In mid 2004, South Korea, Japan and China were reported to be collaborating on $4 \mathrm{G}$ technology.
} 
expensive foreign IPR. In part the source of these policies lie with China's so-called "technology trap". According to Kennedy (2006), despite progress on a number of dimensions of technological development (including a manned space program), China is still dealing with problems which are seen as frustrating indigenous technological progress. China's patenting activity is seen as disappointing and Chinese products rarely incorporate indigenous intellectual property. In turn, China's remarkable growth as a center of manufacturing and emergence as a significant exporter of high-technology goods still involves dependence on foreign technologies that has seemingly deepened following China's accession to the WTO.

China's determination to escape from a "technology trap" is best reflected in The Guidelines on National Medium- and Long-term Program for Science and Technology Development 2006-2020 released in early 2006. Next generation of wireless broadband technology (e.g. 3G, beyond 3G/4G, etc.) is listed as one of the most important technology development projects - Mega Projects. In addition to the general targets of technology development such as patent accumulation and talent cultivation, 3G and other indigenous standards setting initiatives are expected to contribute to the establishment of vertically-integrated industry chains and support for enterprises instead of government research institutes is to play a dominant role in the indigenous innovation system ${ }^{45}$.

These strategies respond to China's widely recognized weaknesses in domestic science and technology development, including low enterprise R\&D and government research institutes with limited connections to industry. Given the increasingly aggressive IPR strategy adopted by western countries, China is seen as needing to shift from a high degree of dependence on foreign technology to the development of indigenous technology.

Western scholars usually argue that these weaknesses are fundamentally attributed to China's weak IPRs regime (e.g., Kennedy, 2006). Though recently a small but growing number

\footnotetext{
45 There is no official document release for $3 \mathrm{G}$ development strategy, but one for another indigenous Chinese standard RFID was released in 2006 titled China RFID Technology Policy White Paper. These two points were stated clearly in that official document.
} 
of papers have challenged the validity of current patent systems and advocate change (e.g., Farrell and Shapiro, 2008), the Chinese government seems to prefer to gradually strengthen the existing regime. The implementation of this involves other related areas such as antitrust law and venture capital market development.

A point of debate between indigenous standard support and new technology development is that with increasing returns due to network effects or learning-by-doing, the market might adopt an inferior technology (Arthur, 1989; Cowan, 1991; Shy, 2001; David, 1985; etc.). Some counter arguments have been made. For example, Cowan (1991) emphasized that it was difficult to identify the best technology for those with uncertain merits. Bassanini and Dosi (1998) proposed that in a market with rapid technological change, no predictions can be made by simply looking at theoretical considerations alone. Thus with high uncertainty of outcomes in this industry, Chinese government support for TD-SCDMA should perhaps remain as cautious and gradual ${ }^{46}$.

Therefore, China's strategy for extensive government involvement in standards setting and its commercialization, as in the case of TD-SCDMA, thus need to also be seen relative to these constraints and the broader objectives of development policy. But whether effective commercialization can be achieved at reasonable cost, and how easy further international negotiation will be remains unproven. At the end of the day TD-SCDMA may remain for a whole as largely a standard for the domestic Chinese market on which future development can build, and it can evolve into a 4G standard. The saving in foreign license fees may still justify the financial investment in the standard, and if this is so this approach may be the one used with future standards initiatives.

\footnotetext{
46 As a matter of fact, Chinese government support to TD-SCDMA during its commercialization has been cautious and gradual, which is partly reflected in the planned licensing covering three standards instead of one for TD-SCDMA.
} 


\section{Concluding Remarks}

In this paper we discuss Chinese experience with both international negotiation of $3 \mathrm{G}$ standard (TD-SCDMA) and its subsequent commercialization. Our discussion is in the context of China's wider development strategy based on quality upgrading, and achieving an innovative economy. Standards setting in telecom used to be an area reserved for developed countries. Chinese entry into this field has aroused great interests as well as doubts. In view of the highly intensive R\&D investment required for standard development and deployment, together with the complicated negotiation in global standards competition, it seems to be ambitious for China to develop the TD-SCDMA initiative. And although Chinese efforts have resulted in some progress, it is still uncertain how successful the TD-SCDMA strategy will be and by how much China can benefit. But even if its deployment is mainly in the Chinese market, the savings in foreign license fees may justify the effort.

This paper first describes briefly the general wireless standardization process and the main Chinese and international organizations involved in $3 \mathrm{G}$ standards negotiation. It then provides background to Chinese major stakeholders in $3 \mathrm{G}$ standardization together with documentation of China's 3G experience of attempts to commercialize. This raises several issues concerning both the proposal process and commercialization as well as its prospective evolution to $4 \mathrm{G}$ and an alternative technology - WiMAX.

Due to the complex and evolving nature of wireless technology, it is hard to tell which standard will prove stronger in the long term. Wireless technology experts claim that each have their own advantages which can also be integrated together (Gessler, 2002). At later stages of 3G harmonization under ITU, the concept of family technology arose with multi radio access 
technologies grouped together providing interconnection between them to ensure seamless roaming. The key blocking factor for technology integration is intellectual property. With learning by doing/using, China now has the possibility to take part in future market developments. But a lot of detail will determine success or failure of standard setting initiatives, such as R\&D cooperation, financing mechanisms, IPR negotiation and others. The emergence of a WiMAX-based standard will likely have substantial impact on the value of the TD-SCDMA standard as well as other wireless technologies.

In conclusion, wireless standard competition is dynamic and hard to predict in outcome, and the technologies involved are extremely complex. What China has done in the $3 \mathrm{G}$ area may prove to be pragmatic and well-founded, but how much the intervention will cost in the long term and with what return is unclear. As the nature of high technology is high-risk and high-uncertainty, it is hard to predict whether this Chinese homegrown $3 \mathrm{G}$ standard will succeed or not, or how big a market share it can gain. However, even it fails to gain a significant international market share, the domestic market deployment may cover its R\&D investment and infrastructure deployment. Its impact on national innovative capacity accumulation and international competitiveness can also still be substantial from a long-term point of view as long as China holds to its current development strategy. 
Appendix A

TD-SCDMA Industry Alliance Members and Their Major Specialization

\begin{tabular}{|c|c|c|}
\hline $\begin{array}{l}\text { Specialized } \\
\text { Areas }\end{array}$ & Company & Brief Description \\
\hline \multirow[t]{7}{*}{$\begin{array}{l}\text { Chipset } \\
\text { solution }\end{array}$} & T3G Technology Co. Ltd & $\begin{array}{l}\text { State-enterprise. } \\
\text { Incorporated in Jan } 2003 \\
\text { A joint venture of Philips, Datang Mobile, Samsung and Motorola. T3G's founding } \\
\text { partners are Philips, Datang Mobile, Samsung, Motorola joined and became a new } \\
\text { investor in Jan } 2005 .\end{array}$ \\
\hline & Commit Inc. & $\begin{array}{l}\text { State enterprise. } \\
\text { Established in February } 2002 \text {. } \\
\text { Investors consisting of } 17 \text { well-known enterprises such as China Potevio Corporation, } \\
\text { China Academy of Telecommunications Technology (CATT), Texas Instruments } \\
\text { (China), Nokia (China) Investment Co. Limited, LG Electronics, Inc., and Hyper Market } \\
\text { International Limited and etc. }\end{array}$ \\
\hline & $\begin{array}{l}\text { China Academy of } \\
\text { Telecommunications } \\
\text { Technology / Datang } \\
\text { Telecom Technology and } \\
\text { Industry Group }\end{array}$ & $\begin{array}{l}\text { State enterprise. } \\
\text { Its subsidiary -- China mobile, established in 2002, is the major sponsor of TD-SCDMA } \\
\text { Partnering with Nortel, Alcatel, etc. } \\
\text { Product coverage: chipset, terminal, base station, etc. }\end{array}$ \\
\hline & $\begin{array}{l}\text { Spreadtrum } \\
\text { Communications }\end{array}$ & $\begin{array}{l}\text { Established in } 2001 \text { by } 17 \text { overseas Chinese entrepreneurs, headquartered in Silicon } \\
\text { Valley, with several branch offices in China. }\end{array}$ \\
\hline & $\begin{array}{l}\text { Chongqing } \quad \text { Chongyou } \\
\text { Information Technology } \\
\text { Co., Ltd }\end{array}$ & $\begin{array}{l}\text { State enterprise } \\
\text { Funded mainly by Chongqing Post and Telecom University, partly from government. }\end{array}$ \\
\hline & Comlent & TD-SCDMA RF IC chip, base band chip. \\
\hline & RDA Microelectronics & $\begin{array}{l}\text { founded in } 2004 \text { in Shanghai with funding from the world's premier Private Equity } \\
\text { Funds }\end{array}$ \\
\hline \multirow[t]{2}{*}{ Software } & Koretide Corporation & $\begin{array}{l}\text { Established in June of } 2000 \text {, } \\
3 G \text { operating system }\end{array}$ \\
\hline & $\begin{array}{l}\text { Bright Oceans } \\
\text { Inter-Telecom Corporation }\end{array}$ & A public high-tech enterprise listed on the Shanghai Stock Exchange since 2000 \\
\hline \multirow[t]{6}{*}{ Handset } & Hisense Group & Established in 1994 \\
\hline & $\begin{array}{l}\text { SHANGHAI DBTEL } \\
\text { Industry CO. Ltd }\end{array}$ & Established in 1993, subsidiary of Taiwan DBTEL group \\
\hline & UTStarcom & $\begin{array}{l}\text { headquartered in the Silicon Valley in US with more than } 10 \text { R\&D centers in the US, } \\
\text { China, India, Korea and Canada. }\end{array}$ \\
\hline & Haier Mobile & \\
\hline & $\begin{array}{l}\text { China } \\
\text { Corporation }\end{array}$ & State-enterprise \\
\hline & $\begin{array}{l}\text { Inventec Appliances } \\
\text { (Shanghai) Co., Ltd. }\end{array}$ & a foreign-funded IT enterprise established in Shanghai as early as 1991 \\
\hline
\end{tabular}




\begin{tabular}{|c|c|c|}
\hline & $\begin{array}{l}\text { TCL Mobile } \\
\text { Communication Co., Ltd }\end{array}$ & set up in 1999 \\
\hline & Legend (Beijing) Ltd. & \\
\hline & Holley Group & a privately owned incorporation \\
\hline & Yulong & \\
\hline & Ningbo BIRD Co., Ltd & A Chinese enterprise \\
\hline & Shanghai Simcom & $\begin{array}{l}\text { The first research and development subsidiary company of SIM Technology Group, a } \\
\text { listed company on the Hong Kong Stock Exchange }\end{array}$ \\
\hline & Longcheer Group & \\
\hline \multirow[t]{4}{*}{ Antenna } & Zhongshan Tongyu & \\
\hline & $\begin{array}{l}\text { Xi'an Haitian Antenna } \\
\text { Technologies Co., Ltd. }\end{array}$ & a high-tech stock enterprise \\
\hline & Andrew & Foreign company \\
\hline & MOBI & \\
\hline \multirow[t]{10}{*}{$\begin{array}{l}\text { Infrastructure } \\
\text { Equipment }\end{array}$} & Huawei Technologies Ltd. & $\begin{array}{l}\text { Partnering with Siemens Communications Group, TD Tech Ltd. was formally } \\
\text { established on March 18, } 2005 \text { in Beijing. }\end{array}$ \\
\hline & ZTE Corporation & $\begin{array}{l}\text { Founded in 1985, China's largest listed telecommunications manufacturer and } \\
\text { wireless solutions provider. }\end{array}$ \\
\hline & Potevio Corporation & $\begin{array}{l}\text { state enterprise } \\
\text { founded in } 1980 \text {, originally called China Posts and Telecommunications Industry } \\
\text { Corporation }\end{array}$ \\
\hline & Alcatel Shanghai Bell & the first foreign invested company with a share in China's telecommunications industry \\
\hline & $\begin{array}{l}\text { Guangzhou New Postcom } \\
\text { Equipment Co. Ltd. }\end{array}$ & \\
\hline & $\begin{array}{l}\text { FiberHome Technologies } \\
\text { Group }\end{array}$ & Descendant of Wuhan Research Institute of Post and Telecommunications \\
\hline & Comba Telecom Systems & Comba listed on the Hong Kong Stock Exchange in 2003 \\
\hline & ACE Achieve Group & A Chinese high-tech enterprise \\
\hline & $\begin{array}{l}\text { Shenzhen CFC Network } \\
\text { Technology Co., Ltd. }\end{array}$ & A Chinese high-tech enterprise \\
\hline & $\begin{array}{lr}\text { China } & \text { Electronics } \\
\text { Technology } & \text { Group } \\
\text { Corporation No } 14 \text { Institute }\end{array}$ & China Electronics Technology Group Corporation is a State Key Enterprise. \\
\hline \multirow[t]{3}{*}{$\begin{array}{l}\text { Testing } \\
\text { Instruments }\end{array}$} & $\begin{array}{l}\text { Beijing Zhong Chuang } \\
\text { Telecom Test Co., Ltd. } \\
\text { (ZCTT) }\end{array}$ & A Chinese high-tech enterprise, established in 1995 and went public in 2003 \\
\hline & $\begin{array}{l}\text { Hubei Zhongyou } \\
\text { Technology Industry \& } \\
\text { Commerce Co. ,Ltd. }\end{array}$ & A Chinese high-tech enterprise \\
\hline & $\begin{array}{l}\text { Beijing StarPoint } \\
\text { Telecommunications } \\
\text { Software Co., Ltd. }\end{array}$ & \\
\hline
\end{tabular}




\begin{tabular}{|l|lr|l|}
\hline & China & Electronics & China Electronics Technology Group Corporation is a State Key Enterprise. \\
Technology & Group & \\
& Corporation No 41 Institute & \\
\hline
\end{tabular}

Notes: State Key Enterprises are directly under the leadership of the State-owned Assets Supervision and Administration Commission of the State Council (SASAC)

Sources: Yihui Lu (2007), Chinese Strategy for Developing Indigenous Standards based on the Commercialization Experience of Chinese Indigenous 3G standard, ITIS Industry Observation (in Chinese) and companies' websites.

\section{Appendix B 10 Cities' TD-SCDMA Infrastructure Network Construction}

\begin{tabular}{|c|c|c|c|c|c|c|c|}
\hline \multirow[b]{2}{*}{ Tenderee } & \multirow[b]{2}{*}{ City } & \multicolumn{5}{|c|}{ Main Suppliers } & \multirow[b]{2}{*}{ Network construction progress } \\
\hline & & ZTE & $\begin{array}{l}\text { Datang } \\
\text { Telecom }\end{array}$ & TD Tech & Potevio & $\begin{array}{l}\text { New } \\
\text { Postcom }\end{array}$ & \\
\hline \multirow{8}{*}{$\begin{array}{l}\text { China } \\
\text { Mobile }\end{array}$} & Beijing & $\sqrt{ }$ & & & & & $\begin{array}{l}\text { More than } 2000 \text { base stations. ZTE } \\
\text { occupies all. }\end{array}$ \\
\hline & Shanghai & & $\sqrt{ }$ & & & $\sqrt{ }$ & More than 2000 base stations. \\
\hline & Guangzhou & & $\sqrt{ }$ & & & $\sqrt{ }$ & $\begin{array}{l}2116 \text { base stations by November } \\
2007 \text {, covering } 1153 \mathrm{~km} 2\end{array}$ \\
\hline & Shenzhen & $\sqrt{ }$ & & $\sqrt{ }$ & & & About 2000 base stations. \\
\hline & Tianjin & $\sqrt{ }$ & & & $\sqrt{ }$ & & $\begin{array}{l}\text { Completed by October } 2007 . \text { ZTE } \\
\text { and Potevio share the market. }\end{array}$ \\
\hline & Shenyang & $\sqrt{ }$ & & $\sqrt{ }$ & & & \\
\hline & Qinhuangdao & $\sqrt{ }$ & & & $\sqrt{ }$ & & $\begin{array}{l}\text { Completed by August } 2007 \text {. ZTE } \\
\text { and Potevio share the market. }\end{array}$ \\
\hline & Xiamen & $\sqrt{ }$ & & $\sqrt{ }$ & & & $\begin{array}{l}\text { About } 150 \text { base stations completed } \\
\text { by September } 2007 \text {, shared by } \\
\text { ZTE and TD Tech. }\end{array}$ \\
\hline $\begin{array}{l}\text { China } \\
\text { Telecom }\end{array}$ & Baoding & & $\checkmark$ & $\sqrt{ }$ & & & $\begin{array}{l}104 \text { base stations in Stage 1; } 100 \\
\text { base stations in Stage } 2 \text { (finished } \\
92 \% \text { ). tender for Stage 2: } 0.82 \\
\text { billion RMB. }\end{array}$ \\
\hline $\begin{array}{l}\text { China } \\
\text { Netcom }\end{array}$ & Qingdao & $\sqrt{ }$ & $\sqrt{ }$ & & & & $\begin{array}{l}150 \text { base stations in Stage } 1 ; 300 \\
\text { base stations in Stage } 2 \text {. Tender for } \\
\text { Stage } 2 \text { is } 0.8 \text { billion RMB. ZTE } \\
\text { and Datang ASB: } 50 \% \text { to } 50 \% \text {. }\end{array}$ \\
\hline
\end{tabular}

Source: Liu, Jing (2008) "TD-SCDMA in 10 Cities: Facing Network Test”, China Electronics News.

Available online <http://www.cena.com.cn/Article/tongxin/TDzhuanti/2008-03-14/20080314135803_6810.shtml> 


\section{References}

Arthur, W. B., 1994. Increasing Returns and Path Dependence in the Economy. Ann Arbor: University of Michigan Press.

Arthur. W. B. 1989. Competing technologies, increasing returns, and lock-in by historical events. Economic Journal 97: 642-65.

Bassanini, A. and G. Dosi, 1998. Competing Technologies, International Diffusion and the Rate of Convergence to a Stable market structure, IIASA Interim Report \# IR-98-012.

Bauer, J. and Lin, Y.C., 2004. Transition Paths to Next-Generation Wireless Devices, Paper prepared for presentation at the 32nd Research Conference on Communication, Information and Internet Policy Arlington, VA, October 1-3, 2004.

Cowan, R., 1991. Tortoises and hairs: choice among technologies of unknown merit. Economic Journal $101,801-814$.

David, P., 1985. Clio and the Economics of QWERT, The American Economic Review Papers and Proceedings, Vol. 75, No. 2, pp. 332-337.

Farrell, J. and Shapiro, C., 2008. How Strong Are Weak Patents? American Economic Review, vol. 98, no. 4, pp. 1347-1369.

Gandal, N., Salant, D. and Waverman, L., 2003. Standards in Wireless Telephone Networks, Telecommunications Policy, 27:325-332.

Gessler, F., 2002. The Development of Wireless Infrastructure Standards, PhD dissertation submitted to the Royal Institute of Technology, Industrial Economics and Management, Stockholm.

Katz, M. and Shapiro, C., 1985. Network Externalities, Competition and Compatibility, American Economi Heinrich Freiherr von Stackelberg, 1934, Marktform und Gleichgewicht (Market Structure and Equilibrium), Vienna.view, vol. 75 (3), pp. 424-440

Kennedy, S., 2006. The political economy of standards coalitions: Explaining China's involvement in standards wars. Asia Policy, 2, 41-62.

Laffont, J.J. and Tirole, J., 2000. Competition in Telecommunications. Cambridge, Massachusettes: The MIT Press.

Liu, G., Zhang, J., Zhang, P., Wang, Y., Liu, X. and Li, S., 2006. Evolution Map from TD-SCDMA to FuTURE B3G TDD, Communications Magazine, IEEE, Vol. 44, Issue 3, pp. 54-61.

Qiao, N. and Lu, Y., TD-SCDMA Legend, http://www.cww.net.cn/zhuanti/td_scdma/default.html

Ryan, P., 2005. The Future of the ITU and its Standard-Setting Functions in Spectrum Management, Standards Edge: Future Generation, Sherrie Bolin, ed., p. 341, Sheridan Books. 
Shy, O., 2001. The Economics of Network Industries, Cambridge University Press.

Suttmeier P., Yao, X. and Tan, A., 2006. Standards of Power? Technology, Institutions, and Politics in the Development of China's National Standards Strategy, NBR Special Report. National Bureau of Asian Research.

von Stackelberg, H.F., 1934. Marktform und Gleichgewicht (Market Structure and Equilibrium), Vienna.

Whalley, J. and Zhou, W., 2007. Technology Upgrading and China's Growth Strategy to 2020, CIGI Working Paper No. 21.

Zhang, P. and Li, L., 2003. Research and Demonstration on Beyond 3G Systems, The $14^{\text {th }}$ IEEE 2003 International Symposium on Personal, lndoor and Mobile Radio Communication Proceedings, pp.1919. 


\section{CESifo Working Paper Series}

for full list see www.cesifo-group.org/wp

(address: Poschingerstr. 5, 81679 Munich, Germany, office@cesifo.de)

2477 Gaëtan Nicodème, Corporate Income Tax and Economic Distortions, November 2008

2478 Martin Jacob, Rainer Niemann and Martin Weiss, The Rich Demystified - A Reply to Bach, Corneo, and Steiner (2008), November 2008

2479 Scott Alan Carson, Demographic, Residential, and Socioeconomic Effects on the Distribution of $19^{\text {th }}$ Century African-American Stature, November 2008

2480 Burkhard Heer and Andreas Irmen, Population, Pensions, and Endogenous Economic Growth, November 2008

2481 Thomas Aronsson and Erkki Koskela, Optimal Redistributive Taxation and Provision of Public Input Goods in an Economy with Outsourcing and Unemployment, December 2008

2482 Stanley L. Winer, George Tridimas and Walter Hettich, Social Welfare and Coercion in Public Finance, December 2008

2483 Bruno S. Frey and Benno Torgler, Politicians: Be Killed or Survive, December 2008

2484 Thiess Buettner, Nadine Riedel and Marco Runkel, Strategic Consolidation under Formula Apportionment, December 2008

2485 Irani Arraiz, David M. Drukker, Harry H. Kelejian and Ingmar R. Prucha, A Spatial Cliff-Ord-type Model with Heteroskedastic Innovations: Small and Large Sample Results, December 2008

2486 Oliver Falck, Michael Fritsch and Stephan Heblich, The Apple doesn't Fall far from the Tree: Location of Start-Ups Relative to Incumbents, December 2008

2487 Cary Deck and Harris Schlesinger, Exploring Higher-Order Risk Effects, December 2008

2488 Michael Kaganovich and Volker Meier, Social Security Systems, Human Capital, and Growth in a Small Open Economy, December 2008

2489 Mikael Elinder, Henrik Jordahl and Panu Poutvaara, Selfish and Prospective: Theory and Evidence of Pocketbook Voting, December 2008

2490 Maarten Bosker and Harry Garretsen, Economic Geography and Economic Development in Sub-Saharan Africa, December 2008

2491 Urs Fischbacher and Simon Gächter, Social Preferences, Beliefs, and the Dynamics of Free Riding in Public Good Experiments, December 2008 
2492 Michael Hoel, Bush Meets Hotelling: Effects of Improved Renewable Energy Technology on Greenhouse Gas Emissions, December 2008

2493 Christian Bruns and Oliver Himmler, It's the Media, Stupid - How Media Activity Shapes Public Spending, December 2008

2494 Andreas Knabe and Ronnie Schöb, Minimum Wages and their Alternatives: A Critical Assessment, December 2008

2495 Sascha O. Becker, Peter H. Egger, Maximilian von Ehrlich and Robert Fenge, Going NUTS: The Effect of EU Structural Funds on Regional Performance, December 2008

2496 Robert Dur, Gift Exchange in the Workplace: Money or Attention?, December 2008

2497 Scott Alan Carson, Nineteenth Century Black and White US Statures: The Primary Sources of Vitamin D and their Relationship with Height, December 2008

2498 Thomas Crossley and Mario Jametti, Pension Benefit Insurance and Pension Plan Portfolio Choice, December 2008

2499 Sebastian Hauptmeier, Ferdinand Mittermaier and Johannes Rincke, Fiscal Competition over Taxes and Public Inputs: Theory and Evidence, December 2008

2500 Dirk Niepelt, Debt Maturity without Commitment, December 2008

2501 Andrew Clark, Andreas Knabe and Steffen Rätzel, Boon or Bane? Others' Unemployment, Well-being and Job Insecurity, December 2008

2502 Lukas Menkhoff, Rafael R. Rebitzky and Michael Schröder, Heterogeneity in Exchange Rate Expectations: Evidence on the Chartist-Fundamentalist Approach, December 2008

2503 Salvador Barrios, Harry Huizinga, Luc Laeven and Gaëtan Nicodème, International Taxation and Multinational Firm Location Decisions, December 2008

2504 Andreas Irmen, Cross-Country Income Differences and Technology Diffusion in a Competitive World, December 2008

2505 Wenan Fei, Claude Fluet and Harris Schlesinger, Uncertain Bequest Needs and LongTerm Insurance Contracts, December 2008

2506 Wido Geis, Silke Uebelmesser and Martin Werding, How do Migrants Choose their Destination Country? An Analysis of Institutional Determinants, December 2008

2507 Hiroyuki Kasahara and Katsumi Shimotsu, Sequential Estimation of Structural Models with a Fixed Point Constraint, December 2008

2508 Barbara Hofmann, Work Incentives? Ex Post Effects of Unemployment Insurance Sanctions - Evidence from West Germany, December 2008 
2509 Louis Hotte and Stanley L. Winer, The Demands for Environmental Regulation and for Trade in the Presence of Private Mitigation, December 2008

2510 Konstantinos Angelopoulos, Jim Malley and Apostolis Philippopoulos, Welfare Implications of Public Education Spending Rules, December 2008

2511 Robert Orlowski and Regina T. Riphahn, The East German Wage Structure after Transition, December 2008

2512 Michel Beine, Frédéric Docquier and Maurice Schiff, International Migration, Transfers of Norms and Home Country Fertility, December 2008

2513 Dirk Schindler and Benjamin Weigert, Educational and Wage Risk: Social Insurance vs. Quality of Education, December 2008

2514 Bernd Hayo and Stefan Voigt, The Relevance of Judicial Procedure for Economic Growth, December 2008

2515 Bruno S. Frey and Susanne Neckermann, Awards in Economics - Towards a New Field of Inquiry, January 2009

2516 Gregory Gilpin and Michael Kaganovich, The Quantity and Quality of Teachers: A Dynamic Trade-off, January 2009

2517 Sascha O. Becker, Peter H. Egger and Valeria Merlo, How Low Business Tax Rates Attract Multinational Headquarters: Municipality-Level Evidence from Germany, January 2009

2518 Geir H. Bjønnes, Steinar Holden, Dagfinn Rime and Haakon O.Aa. Solheim, ,Large' vs. ,Small' Players: A Closer Look at the Dynamics of Speculative Attacks, January 2009

2519 Jesus Crespo Cuaresma, Gernot Doppelhofer and Martin Feldkircher, The Determinants of Economic Growth in European Regions, January 2009

2520 Salvador Valdés-Prieto, The 2008 Chilean Reform to First-Pillar Pensions, January 2009

2521 Geir B. Asheim and Tapan Mitra, Sustainability and Discounted Utilitarianism in Models of Economic Growth, January 2009

2522 Etienne Farvaque and Gaël Lagadec, Electoral Control when Policies are for Sale, January 2009

2523 Nicholas Barr and Peter Diamond, Reforming Pensions, January 2009

2524 Eric A. Hanushek and Ludger Woessmann, Do Better Schools Lead to More Growth? Cognitive Skills, Economic Outcomes, and Causation, January 2009

2525 Richard Arnott and Eren Inci, The Stability of Downtown Parking and Traffic Congestion, January 2009 
2526 John Whalley, Jun $\mathrm{Yu}$ and Shunming Zhang, Trade Retaliation in a Monetary-Trade Model, January 2009

2527 Mathias Hoffmann and Thomas Nitschka, Securitization of Mortgage Debt, Asset Prices and International Risk Sharing, January 2009

2528 Steven Brakman and Harry Garretsen, Trade and Geography: Paul Krugman and the 2008 Nobel Prize in Economics, January 2009

2529 Bas Jacobs, Dirk Schindler and Hongyan Yang, Optimal Taxation of Risky Human Capital, January 2009

2530 Annette Alstadsæter and Erik Fjærli, Neutral Taxation of Shareholder Income? Corporate Responses to an Announced Dividend Tax, January 2009

2531 Bruno S. Frey and Susanne Neckermann, Academics Appreciate Awards - A New Aspect of Incentives in Research, January 2009

2532 Nannette Lindenberg and Frank Westermann, Common Trends and Common Cycles among Interest Rates of the G7-Countries, January 2009

2533 Erkki Koskela and Jan König, The Role of Profit Sharing in a Dual Labour Market with Flexible Outsourcing, January 2009

2534 Tomasz Michalak, Jacob Engwerda and Joseph Plasmans, Strategic Interactions between Fiscal and Monetary Authorities in a Multi-Country New-Keynesian Model of a Monetary Union, January 2009

2535 Michael Overesch and Johannes Rincke, What Drives Corporate Tax Rates Down? A Reassessment of Globalization, Tax Competition, and Dynamic Adjustment to Shocks, February 2009

2536 Xenia Matschke and Anja Schöttner, Antidumping as Strategic Trade Policy Under Asymmetric Information, February 2009

2537 John Whalley, Weimin Zhou and Xiaopeng An, Chinese Experience with Global 3G Standard-Setting, February 2009 